\title{
Varumärkesfetischism och tidsdetaljer: Om Malmö, Manhattan och Ystads svinalängor
}

\section{Av Magnus Eriksson}

\section{Inledning}

Chick lit är en gränsgenre. Den balanserar romantik- och underhållningsromanens spänningskrav mot en idémässig framtoning som förgrenas ner i Romantikens bildningsroman. Den hävdar också en feministisk medvetenhet, fast denna vanligen har mer gemensamt med Madonna än med Simone de Beauvoir. Det är också en genre som passar väl in i den målgrupp som bokbranschen definierat som "young adults", alltså en publik som förutsätts vilja ha en typ av romaner som intar ett mellanläge mellan ungdomsboken och den roman som inte åldersdefinierats.

Gränsen mellan vad som av hävd betraktas som underhållning respektive seriös litteratur luckras upp från båda håll. I det följande kommer jag därför att fokusera på likheter och skillnader mellan en representativ chick lit och två av det litterära etablissemanget hyllade romaner, båda fick Augustpriset. Analysen tar fasta på chick lit-genrens varumärkesfetischism, som den kommer till uttryck i Plum Sykes roman Bergdorf Blondes (svensk översättning Bergdorfblondiner), och sätter denna i relation till den fetischering av tids- och miljödetaljer vi ser i Torbjörn Flygts roman Underdog. För perspektivets skull jämför jag också med Susanna Alakoskis skapande av en tidsmiljö i Svinalängorna.

\section{Chick lit: romantisk ideologi och varumärkesfetischism}

Två saker slår mig när jag läser chick lit. Den ena är den traditionella kärleksideologin. Chick lit ansluter till den klassiska romantikgenren, på samma sätt som flärdromanen ett årtionde eller två tidigare. Vägen till den sanna kärleken må vara mödosam, men i slutet hittar hjältinnan fram. Men de båda sentida arvtagarna distanserar sig också från romantikromanens hävdvunna mönster. Flärdromanen betonade sexualiteten, ofta på ett fränt sätt. Det förlänade genren äronamn som "tantsnusk" och "the shopping and fucking novel". Men sexualiteten skrevs också in i kärleksideologin. Det var först med den rätte som hjältinnan fick leva ut sin sexualitet på egna villkor. Dessförinnan hade hon skändligen utnyttjats.

Även i chick lit är sexualiteten ett bärande motiv. Genrens hjältinnor vet vanligen vad de vill. Några av dem utnyttjas, andra utnyttjar. Och huvudpersonen finner den sanna kärleken, den som helar henne och råder bot på allt som drabbat henne i det förflutna. Åtminstone oftast, kärleken kan bli en bisak i romanen. Då leder inte alltid skeendet fram till den slutliga föreningen och bekräftelse av en traditionell kärleksideologi. Maria 
Nilson framhåller också i sin bok om genren att en del svenska chick lit-författarinnor avviker från mönstren genom att skriva om "vardagssex", som inte alltid är så glamoröst. ${ }^{1}$

Den andra saken som slår mig är varumärkeshysterin. En sådan fanns också i flärdromanen, men i chick lit svämmar den över alla breddar. Varumärkena står som spön i backen och läsaren upp i halsen. De är så frekventa att de rentav innebär ett läsmotstånd för den som på sin höjd är ytligt bekant med märkes- och designernamn. Så kan även en underhållningsroman utmana läsaren, fast utmaningen ligger helt på ytplanet. Där kan texten bli svårforcerad, någon djupverkan skapar inte varumärkesfetischismen.

Fast buden går isär. I inledningen till antologin Chick Lit: The New Woman's Fiction refererar Suzanne Ferriss och Mallory Young till en studie av Jessica Jernigan, som hävdar att chick lit-genrens intresse för "fashion and cocktails" inte blott är en ytlig samtidsmarkör utan att det också på djupet speglar konsumtionskulturens problem. ${ }^{2}$ Ferriss och Young lägger själva till att många chick lit-romaner "focus on the simultaneous pleasures and dangers of consumerism." De anför Sophie Kinsellas Shopaholic Trilogy som exempel. I sin analys av den romansviten hävdar dock Jessica Lyn Van Slooten att det konsumtionskritiska perspektivet är nertonat. ${ }^{3}$ Hon skriver att konsumtionen främst är ett verktyg för huvudpersonen Becky att skapa och omskapa sin identitet. Becky upprättar listor i sitt inre över sina inköp, där hon anger plagg och märke. Hon beskriver inte sina plagg, hon anger blott märke eller designernamn. Enligt Van Slooten hjälper varumärkena Becky att "create herself as fashionable and trendy". ${ }^{4}$ Det är alltså varumärket, inte plaggets utseende, som är det väsentliga i huvudpersonens identitetsskapande. Van Slooten lägger till att upprättandet av listor, för övrigt ett vanligt inslag i det senaste decenniets populärkultur och populärkulturjournalistik, förstärker Beckys identitet, eller hennes självförståelse.

Juliette Wells generaliserar iakttagelsen, när hon skriver att varor och varumärken är av grundläggande betydelse för genrens hjältinnors "self-conception and selfpresentation". ${ }^{5}$ Det är därför som författarinnorna ägnar lika mycket utrymme år att beskriva anskaffandet av kläder som åt gestalternas utseende.

Varumärkesfetischismen har enligt dessa forskare både tematisk och teknisk signifikans. Konsumtionen är en viktig del av gestalternas identitetsskapande, men varumärkena är också berättartekniskt betydelsefulla som motor i personskildringen. Inget av detta utesluter tanken att chick lit-genrens bild av konsumtionen också rymmer en varning för dess avigsidor. Men frågan är hur det eventuellt kritiska perspektivet kan harmoniseras med den produktplacering som Stephanie Harzewski uppmärksammar, när hon berättar

\footnotetext{
1 Maria Nilson, Chick lit: från glamour till vardagsrealism, Lund: Btj, 2008, sid 93f.

2 Suzanne Ferriss \& Mallory Young, Chick Lit: The New Woman's Fiction, New York: Routledge, $\operatorname{sid} 4$.

3 Jessica Lyn Van Slooten, 'Fashionably Indebted" i Ferriss \& Young, sid 219-238.

4 Van Slooten, sid 224.

5 Juliette Wells, "Mothers of Chick Lit?" i Ferris \& Young, sid 47-70. Citerad passge från sid 62.
} 
om hur huvudpersonen i Carole Matthews roman The Sweetest Taboo körde en Ford Fiesta som en del av en överenskommelse mellan författarinnan och Ford. ${ }^{6}$

\section{Kärlek och varumärken i Bergdorfblondiner}

Både den traditionella kärleksideologin och varumärkesfetischismen präglar Plum Sykes roman The Bergdorf Blondes, 2004.' Enligt Maria Nilson 'lever romanens unga och mycket rika kvinnor ett märkligt låtsasliv, där de på olika sätt försöker lära sig att skickligt manipulera en man till giftermål." ${ }^{\prime}$ Hon skriver vidare om dessa kvinnors önskan att "få en dyrbar förlovningsring och att sedan ha ett underbart och påkostat bröllop."

Romanen är skriven i jag-form. Huvudpersonen och berättaren kallar sig själv "Moi"; namnet syftar snarare på det franska pronomenet än på den feministiska litteraturforskaren Toril Moi. Redan i romanens första mening får vi veta att "Bergdorfblondiner är en grej." ${ }_{10}$ I den följande meningen konstaterar Moi att

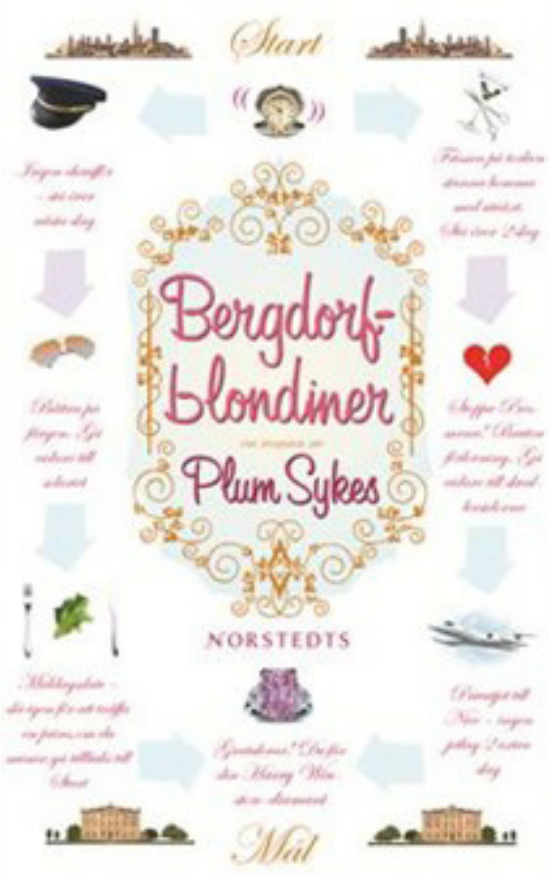
"absolut alla vill vara en, men det är i själva verket très komplicerat." ${ }_{11}$ Inledningen är effektiv. Läsarens uppmärksamhet riktas direkt mot romanens centrala tema, de s k Bergdorfblondinernas liv. Den rymmer också en indirekt personkaraktäristik. Vi får en alls icke särskilt diskret antydan om att Moi både är en beskäftig pladdrare och att hon obekymrat svänger sig med franska ord, som det visar sig företrädesvis pronomenet "moi" och förstärkningsordet "très". Det antyder även en ironisk position, som understryks av att "Moi" lika obekymrat påstår sig tala "flytande franska, emellanåt." ${ }^{12}$ I det första kapitlet upprättar hon också den i genren obligatoriska listan. I sin första lista tecknar "Moi" ner sina karaktärsdrag. Flera listor följer i romanen.

I det första kapitlet anges också ett stort antal varumärken och designernamn: Calvin Klein, Missoniklänningar, Manolo Blahnik, Chloéjeans, Rogan, Seven, Earl, Juicy, Blue Colt, Harry Winstons förlovningsringar, L.L.Bean-ryggsäckar, Hermès Birkin, Chanel, Mendel-minkjackor, Vuitton, Marc Jacobs. Jag kan ha missat några namn, eller blott varit oförmögen att identifiera dem. "Moi" nämner dessutom flera butiker och restauranger.

6 Stephanie Harzewski, "Tradition and Displacement in the New Novel of Manners" i Ferriss \& Young, sid 29-46.

7 Eva Mazetti-Nissens svenska översättning Bergdorfblondiner gavs ut 2006 (Stockholm: Prisma). För citaten som följer hänvisas till pocketutgåvan (Stockholm: Norstedts, 2007).

8 Maria Nilsson, sid 65.

9 Ibid.

10 Plum Sykes, sid 5.

11 Ibid.

12 Plum Sykes, sid 8. 
Men hon skapar också en polaritet som understryker Bergdorfblondinernas egenskaper. "Moi" skriver att hon ibland "ser ut som någon hämtad ur en film typ Fargo."13 Det verkliga skräcktillståndet är alltså att se ut som någon av de skandinavisk-amerikanska gestalterna i bröderna Coens kriminalfilm. Den negativa avgränsningen får ännu en accent i beskrivningen av Julie Bergdorfs, den främsta i kretsen, medievanor: "Julie tycker att New Yorker och reklamfri teve är helt fördärvliga och trista och att alla borde läsa US Weekly och titta på E! istället." ${ }_{14}$

Varumärkena blir en del av romanens normsystem. Det hjälper till att definiera det positiva idealet, det som kontrasterar mot Fargo-människornas tråkiga liv, eller mot New York-intelligentian. Bokens hjältinnor kan få en klänning influgen från Paris med Federal Express. De lägger astronomiska summor på hårslingor, och deras exklusiva skor, byxor och klänningar namnges omsorgsfullt. Men Juliette Wells iakttagelse att namngivandet är viktigare än beskrivningen $i$ chick lit gäller inte fullt ut. I varumärkesrabblandet smyger sig även in ett eller annat ord som berättar om plaggets färg eller längd.

Varumärkena används också för att skapa det första intrycket när en ny gestalt introduceras: "Muffy hade på sig en Oscar de la Renta-poncho med fransar, limegröna stuprörssmala byxor och tillräckligt med smycken för att tömma en diamantgruva." ${ }_{15}$ Även om bara ett namn nämns, ger det den första associationen i den bild som sedan byggs ut med ett par till sin form beskrivna byxor och till sin mängd beskrivna diamantsmycken. Varumärkena bidrar också till den indirekta personbeskrivningen. När "Moi" grälar med en av sina älskare utbrister denne: "Du skulle inte märka en apokalyps om den inte var försedd med Gucci-etikett." ${ }^{16}$ Reaktionen är belysande: "'Det är faktiskt Chloé som är min grej’, viskade jag sorgset. Han visste ingenting om mig, inte ens någonting så stort." ${ }_{17}$

Passagen kan naturligtvis tolkas konsumtionskritiskt, som en bild av det sociala och existentiella främlingskap som den rastlösa jakten på konsumtionskickar skapar. Men då skulle romanen som helhet kunna reduceras till den bilden. Det vore förödande, eftersom texten i så fall skulle bli ytterligt redundant eller tautologisk. Snart sagt vartenda ord i boken kunde då anföras som stöd för den kritiska idén utan att den fördjupas eller förtydligas; den skulle endast få en additiv tillväxt, som en allt större mängd av utsagor med identisk betydelse. Och vart tar underhållningsvärdet vägen i en sådan läsning?

Varumärkena och designernamnen är en del av romanens konkreta referenssystem. En annan del utgörs av filmer, tv-serier och tidskrifter; beskrivnigen av Julie Bergdorfs medievanor är en del av detta, liksom skräcken för att se ut som en Fargo-gestalt. Men romanen ger fler exempel. "Moi” berättar att New Yorks dejtningskultur är värre än i Sex and the City. När hon skriver om hur den perfekta mannen påverkar henne, jämför hon med filmer som Casablanca och The Talented Mr Ripley och ett "pas de deux ur

13 Plum Sykes, sid 6.

14 Plum Sykes, sid 12.

15 Plum Sykes, sid 32.

16 Plum Sykes, sid 95.

17 Ibid. 
Svansjön."18 Plum Sykes låter sin berättare växla mellan kommersiella underhållningsprodukter och högkulturella verk, vilket kunde rymma en kritisk udd mot en konservativ hierarkisering av kulturella uttryck. Men hon ger också en ironisk släng åt en sådan förståelse när hon låter "Moi" utveckla sin idé om den ideale mannen: "Enligt de romantikens lagar som jag lärt mig av klassiska filmer som Sömnlös i Seattle finns det bara en Den Ende och det finns inget man kan göra åt det." ${ }_{19}$

Nora Ephrons film Sleepless in Seattle gjordes 1993, elva år innan Plum Sykes gav ut sin roman. Endast en filmhistorisk oskuld skulle ens idag kalla filmen en klassiker. Kritiken av en kulturkonservativ hierarkisering skulle också omfattat ett kritiskt ifrågasättande av kanonisering och klassikerbegrepp. Den läsningen förblir hypotetisk. Den obesvärade vandringen i filmhistorien antyder snarast att "Moi" är oreflekterad, inte att hon skulle vara medvetet kritisk mot hierarkiseringen.

Det är alltså svårt att passa in Bergdorfblondiner i Jessica Jernigans idé att chick lit kritiserar konsumtionskulturen. I Plum Sykes roman ser vi i stället en fetischering av konsumtionssamhällets mest exklusiva produkter. Perspektivet bekräftas av en berättare som pladdrar på, glatt obekymrad om vad hon egentligen säger. Jämför gärna med Saul Bellows roman More Die of Heartbreak, 1987, vars berättare Kenneth Trachtenberg å det vidlyftigaste lägger ut sin filosofi och sina idéer om bland annat de amerikanska universiteten. Hos Bellow handlar det om ett annat segment i samhället och syftet är tydligare kritiskt, men sättet att använda tekniken med den självavslöjande berättaren påminner om Plym Sykes pladdrande "Moi".

Hos Plum Sykes har inte varumärkesrabblandet något kritiskt syfte. Varumärkenas primära funtion är i stället att skapa den positiva delen av en normativ polaritet (där Fargo-gestalterna och New Yorker-läsarna utgör den negativa polen). När de rusar förbi läsarens ögon skapar varumärkena dessutom ett intryck av det naturliga, av en värld där vi alla - författaren, hennes gestalter, läsarna - hemtamt rör sig. Det självklara behöver inte beskrivas. Beskrivningen är främlingens perspektiv. Det självklara pekas ut genom omnämnanden, som om den värld texten upprättar redan är känd av läsaren.

Men den världen utgör också en social miljö, som formas av sin tid. Varumärkena signalerar social tillhörighet och en given tid. Referenserna är så precisa att tiden går att ringas in. Den utgör ett tvärsnitt av den i texten frammanade världens alla positivt konnoterade varumärken och designernamn. En inte alltför djärv gissning skulle peka ut åren runt dess utgivning som romanens tidsmiljö, dess sociala miljö är uppenbar. Frågan blir hur romanen läses när Chloéjeansen eller Manolo Blahniks skor inte längre åtnjuter samma prestige och värdeladdning som när boken gavs ut, eller när de fallit ur läsarnas gemensamma minne. Kommer romanerna att fungera som vittnesbörd om en tid, eller som tecken på den? Kanske ger referenserna mer allmänna och mindre individualiserade signaler om flyktig rikedom och lycka? Eller kommer romanerna att i någon mening av ordet bli obegripliga?

19 Plum Sykes, sid 87. 


\section{Tidsdetaljerna i Underdog}

I chick lit skapar namnen och varumärkena samtidskänsla. Men även i romaner som utspelas i det nära förflutna är konkreta och lätt identifierbara referenser viktiga för tidsmiljön. I några av de senaste årens mest framgångsrika svenska romaner, både kritiskt och kommersiellt, kan vi se hur författarna ger bilden av en tid med en metod som minner om chick lit-genrens.

I Underdog, som belönades med Augustpriset år 2001, berättar Torbjörn Flygt om sin uppväxtstad Malmö. Han fokuserar på sin egen barn- och ungdomstid på 1970-talet, men han skriver från den vuxne mannens perspektiv och drar linjerna in i sin, och läsarens, samtid. År 2006 belönades Susanna Alakoski med Augustpriset för sin roman Svinalän-

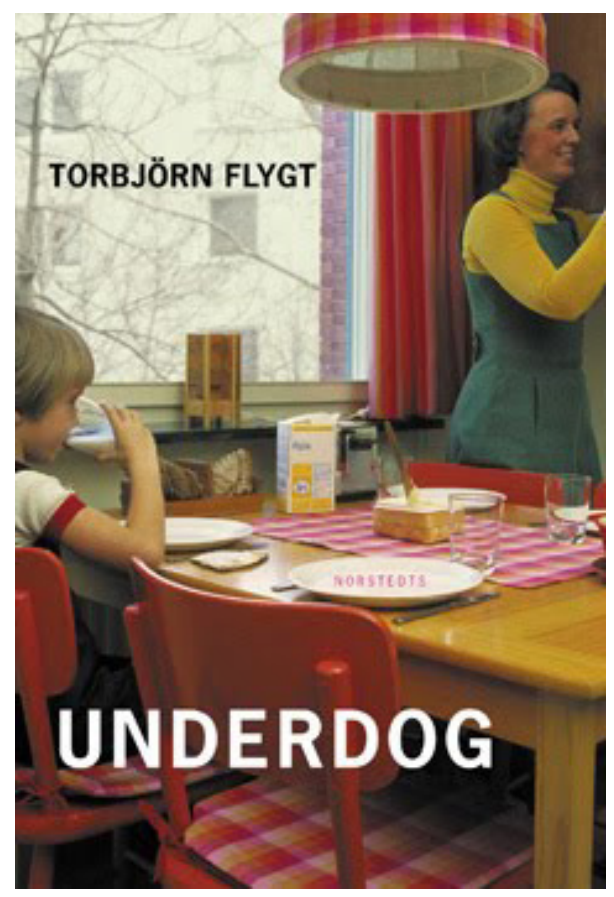
gorna. Den handlar om 1960-talets Ystad. Båda författarna skriver om staden där de växte upp, och miljöerna är lätt igenkännbara. Böckerna är skrivna i jag-form, och med hjälp av noggrant inprickade detaljer manar författarna fram en värld ur det nära förflutna, men också en värld som kan kännas avlägsen. Det är också uppenbart att båda författarna vädjar till de läsare som minns den tid de skriver om. Tidsdetaljerna liksom jag-perspektivet manar läsarna att närmast identifikatoriskt träda in i det återkallade förflutna. Inte minst i fråga om Underdog har det också stadfästs en bild av att författaren vällustigt vältrar sig i tidsdetaljer. Skulle ett sådant vältrande kunna jämföras med chick lit-genrens varumärkesfetischism?

Torbjörn Flygt skapar sin tidsmiljö främst genom referenser till musik, idrott och sociala skeenden. Hans roman är en utpräglad proletärroman, och vi får nära följa berättarjagets mors erfarenhet från Malmö strumpfabrik, den s.k. "Strumpan". När Flygt renodlar den vuxne mannens perspektiv, sätter han också in de sociala skeendena i ett större sammanhang genom jämförelser med de decennier som följde. Där är perspektivet kritiskt. Flygt ger inte en nostalgisk bild av det politiska 1970-talet, men det är uppenbart att han anser att det mesta blev värre därefter.

Musiken har också en framträdande roll i romanen. Namn som Hoola Bandoola Band, Nationalteatern och David Bowie sveper förbi. De markerar första halvan av decenniet. Sedan kommer punkrevolten och namn som Sex Pistols och Tom Robinson Band. När huvudpersonen Johan kommer upp en bit i tonåren och hans syster Monika tar stegen in i en vuxentillvaro (universitet, egen lägenhet) markeras tiden av namn som Bruce Springsteen, Jackson Browne och John Mellencamp. De båda förra kunde även signalerat 1970-talets första hälft, men deras frånvaro där understryker det sociala perspektivet. Springsteen fick sitt genombrott hos en bredare publik i Sverige först med tredje albumet Born to Run 1975, och Jackson Browne har alltid haft sin publik främst 
bland något äldre, musikaliskt medvetna entusiaster. Även de namnen faller på plats i tidsmiljön.

Det är slående att Torbjörn Flygts konkreta referenser inte i första hand naglar fast ett årtal, utan snarare en tid, eller ett tidsspann som omfattar några år. Bilden av en barndom som inte riktigt vill kännas vid årsskiftena understryks av passager som den här:

"För på lördagarna ska mormor lyssna på radio, först med en kopp kaffe till Ring så spelar vi, där den ena lustiga dialekten avlöser den andra när svenska folket stiger upp tidigt och ställer sig i telefonkö för att prata väder och division tre-bandy med Hasse Tellemar, och därefter skurar hon golven till Melodikrysset med Bengt Haslum."”o

Referenser av det här slaget kan verka konkreta, men i själva verket är de förhållandevis abstrakta. Vi vet att vi befinner oss i 1970-talet, men när? Hasse Tellemar debuterade som programledare för Ring så spelar vi sent 1969, Bengt Haslum i Melodikrysset först 1976. Flygt skapar en syntetisk bild av årtiondet. Den tendensen präglar även de flesta av musik- och idrottsreferenserna. Tidigt i boken berättar Johan om hur han och kompisarna bråkade om vem som skulle vara vilken stjärna när de delade upp i olika lag. Namnen Ronnie Hellström, Ralf Edström, Roland Sandberg, Johan Cruyff, Gerd Müller, Johan Neeskens och Franz Beckenbauer susar förbi. VM-fotbollen har gjort intryck, men handlar det om 1974 eller 1978?

En fotbollsentusiast med gott minne eller Brunnhages fotbollsböcker i bokhyllan inser att det är 1974, eftersom varken Müller, Beckenbauer eller Cruyff spelade för sina respektive landslag i VM 1978. Dessutom saknas världsmästarna från 1978 Mario Kempes och Osvaldo Ardiles bland de åkallade stjärnorna. Men för andra läsare ger nog Flygt en mer allmän bild av 1970-talets fotboll. Den syntetiska tendensen i hans tidsskildring bekräftas även av passager som den om lärarna "som låter oss sitta inne på rasterna och se Stenmark ta hem världscupen i år med." ${ }^{\prime 2}$ Ingemar Stenmark vann den totala världscupen tre gånger på 1970-talet och världscupen i de enskilda slalomgrenarna än fler gånger.

De flesta tidsmarkörerna i Underdog är av syntetisk art. De hänvisar till ett förhållandevis obestämt 1970-tal i stället för att tydligt definiera det. Men Torbjörn Flygt sticker in korta passager som direkt pekar ut vilket år det handlar om, som för att ändå hålla fast en tidslinje i skeendet. En av Johans kamrater har varit på Cypern under sommaren, men fick "evakueras". ${ }^{22}$ Då skriver vi 1974. När Monika går på en alternativfestival därför att "schlagerfestivaler är omoraliska" ${ }^{23}$ har vi kommit till 1975. Det året bekräftas i beskrivningar av den varma sommaren och kravallerna i Båstad under Davis Cup-matchen mot Chile. Att Sverige får en ny regering "efter 44 socialdemokratiska år" ${ }^{24}$ markerar att vi är framme vid 1976. Björn Borgs Wimbledonfinal mot Jimmy Con-

20 Torbjörn Flygt, Underdog, Stockholm: Norstedts, 2011, sid 86. Romanen publicerades först år 2001, men för citaten hänvisas till den senare pocketutgåvan.

21 Torbjörn Flygt, sid 79.

22 Torbjörn Flygt, sid 31.

23 Torbjörn Flygt, sid 72.

24 Torbjörn Flygt, sid 107. 
nors får markera 1977, det svenska fotbollslandslagets bittra matcher mot Österrike och Spanien i VM säger 1978. Så rullar det på.

Torbjörn Flygts roman är rik på tidsbundna referenser, men de pekar oftast på ett längre tidsspann. De precisa referenserna tycks främst ha till uppgift att berätta att ett år till har gått. Detaljerna pekar också på en social miljö, men utgör de ett normsystem som hos Plum Sykes? Vi kan jämföra med musikreferenserna i den brittiske författaren Kazuo Ishiguros novellsamling Nocturnes. ${ }^{25}$ I novellen "Come Rain or Come Shine" skriver Ishiguro om en ung man och en ung kvinna som träffar varandra på universitetet. De delar sin kärlek till klassisk populärmusik, till "The Great American Songbook", till kompositörer som Cole Porter och Irving Berlin och till artister som Julie London och Peggy Lee.

Deras kamrater hyllar den progressiva rockmusiken. Ishiguro nämner inga namn, men en del nyckelord pekar mot gruppen Yes, och kanske även mot de musikaliskt mer vildsinta normbrytarna på Canterbury-scenen. Då drar sig de två vännerna tillbaka och lyssnar på den välgjorda popmusiken, som på trots mot både samtidens kommersialism och musikaliska genreöverskridanden. Men de blir aldrig ett par. Den unga kvinnan gifter sig med en annan. För den forne vännen är dock det sveket ringa jämfört med när han hör henne diskutera någon ny pretentiös rocksvit med andra studentkamrater. Vilken förhärdad opportunist!

I Ishiguros noveller uttrycker musiken en livshållning. I Ian Rankins kriminalromaner, där de musikaliska referenserna är lika legio som varumärkena i en chick lit-roman, står musiken inte blott för en livshållning, utan också för en moralisk och psykologisk kvalitet. Mördarna i en av hans böcker är av någon anledning jazzälskare, medan hans hjältar lyssnar på rockmusik, gärna något äldre sådan.

Hos Ishiguro och Rankin bildar musikreferenserna ett normsystem, precis som varumärkena hos Plum Sykes. Kanske kan den tendensen också skönjas i Underdog, men främst ser vi två andra syften med Flygts tidsdetaljer. Dels ger de en bredare tidsbild, dels prickar de mest i förbigående in vissa år för att visa hur tiden förlöper i romanen. Vi ser då en skillnad mellan en syntetisk (sammanfattad eller utspridd) tid och en konkret, fastnaglad och definierad tid. Varumärken och designernamn i chick lit fyller snarare den senare funktionen, både för att ge samtidskänsla och för att skapa en social miljö.

\section{Tidsmiljön i Svinalängorna}

Tendensen att skapa en syntetisk tid är än tydligare i Susanna Alakoskis Svinalängorna. Alakoski skriver om en mer avgränsad tid än Flygt. Vi får följa huvudpersonen Leena från åren just innan hon börjar skolan upp till högstadieåren. Till skillnad från Flygt skapar Alakoski illusionen att vi får höra den unga Leenas röst i romanen, att det är hon som berättar om vad som hände i ett förhållandevis nära förflutet, från 1960-talets sista år fram till mitten av 1970-talet.

25 Kazuo Ishiguro, Nocturnes, London: Faber and Faber, 2009. 


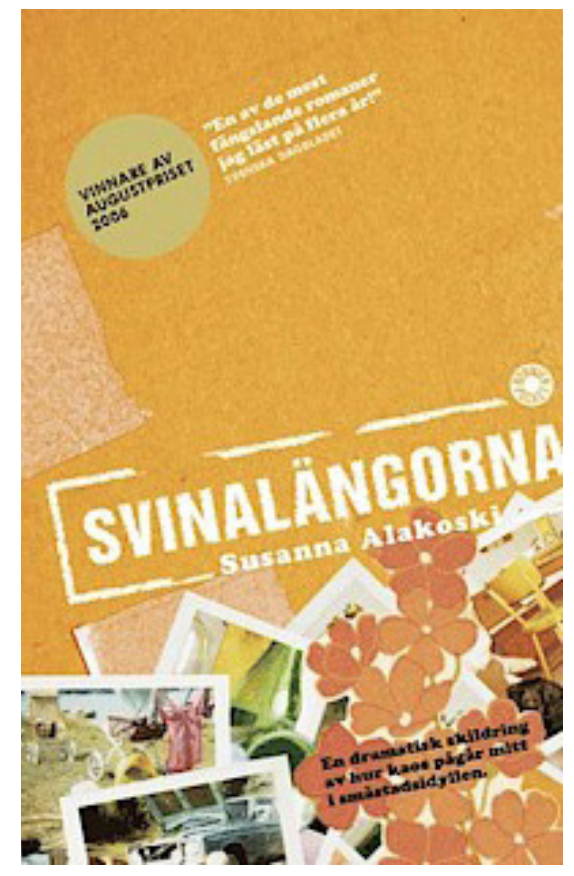

Alakoski är dock sparsam med de precisa tidsmarkörerna. Liksom hos Flygt är det främst musiken och sociala skeenden som pekar ut tiden. Att Leenas familj, som är finska invandrare, flyttar in i ett nybyggt miljonprogramshus i romanens början ger en förankring i tiden. Ytterligare en antydan ges när Leena berättar om familjens vänner och sina egna kamrater. Familjens närmaste vänner är en annan finländsk familj. ’De hade inga LP-skivor", berättar Leena.. ${ }^{26}$ Om kamraten Åses storasyster kan hon i stället säga: "Karin hade både LPskivor och singlar och gardiner i alla fönster." ${ }^{27} \AA$ ren runt 1970 var lp-skivan fortfarande relativt dyr. På den svenska försäljningslistan Kvällstoppen, som sändes varje tisdag, dominerade singelskivor, även om alltfler lp-skivor trängde in på listan. Att en syster till en kamrat hade lp-skivor är något som i Leenas värld var värt att påpeka. Sättet som Alakoski låter Leena tala om dessa skivor får dubbel funktion i texten. Dels förankrar de Leenas berättelse i en social miljö där lp-skivan var något åtråvärt, dels förtydligar de romanens tid. Tiden förtydligas än mer två sidor senare, när vi får veta att Karin hade vita lackstövlar; dessa var på modet kring 1971 .

Annars är Susanna Alakoski sparsam med sådana tidsdetaljer. En bra bit in i romanen talar Leena om maten hemma hos Åses mamma:

"Hon lagade Bongs köttsoppa, Campbell's champinjonsoppa eller fläskkorv med potatis och persiljesås för att det skulle gå fort. Hon stekte frukostkorvar och stuvade makaroner. Stuvade makaroner hemma hos Åse var det bästa jag visste. Mamma kunde inte stuva makaroner. Det var ett svenskt påhitt sa hon. Som att äta kokt vetemjöl. Inte nyttigt för någon. Ibland på söndagar serverade Inga-Lill slottsstek. Ärtor och morötter på burk. Konserverade persikohalvor med kaffegrädde till efterrätt. Eller konserverad cocktailfrukt." 28

Jag är själv född på 1950-talet, och jag känner igen allt. Men det gör nog många som är födda på 1940-talet också, liksom många som är födda långt in på 1960-talet. Det är talande att Susanna Alakoski nöjer sig med två varumärken och att båda är tidlösa. Den omtalade maten förankrar skeendet i en utsträckt tid. Den speglar möjliga matvanor under flera decennier, till dess att de konserverade grönsakerna ersattes av djupfrysta.

Skillnaden mellan den mat Leena får hemma och den som Åses mamma bjuder henne på förstärker den sociala dimensionen i hennes berättelse. Som tidsmarkörer är de däremot mer ungefärliga än varumärkena hos Plum Sykes och Torbjörn Flygts musik- och

26 Susanna Alakoski, Svinalängorna, Stockholm: Bonnier Pocket, 2010, sid 46. Romanen gavs ursprungligen ut 2006, men för citaten hänvisas till en senare pocketupplaga.

27 Susanna Alakoski, sid 55.

28 Susanna Alakoski, sid 59. 
sportreferenser. Även musikreferenserna är viktiga hos Alakoski, men de bidrar också till att skapa ett mer syntetiskt tidsintryck. När Leena berättar om Svensktoppen nämner hon tre sånger: "Där björkarna susa", "Är det konstigt att man längtar bort nån gång" och "Sofia dansar go-go"..29 Den senare låg på Svensktoppen 1972-1973. Det gjorde även "Där björkarna susa" i Hootenanny Singers version. Det är rimligen den som spökar i romanen, inte den mer kända versionen med Jailbird Singers som låg på Svensktoppen 1965. Detta kunde ge en precis tidsram, men "Är det konstigt att man längtar bort nån gång" (Lena Anderssons svenska version av Buffy Sainte-Maries landsbygdsromantiska sång "I'm Gonna Be A Country Girl Again") låg på listan 1971. Någon sida senare berättar Leena att hon fått en låda singlar av en äldre kamrat. Hon nämner flera svensktopps- och poplåtar utgivna mellan 1968 och 1973.

Det viktiga för Susanna Alakoski är uppenbarligen inte att definiera ett avgränsat tidssnitt, utan snarare att skapa en associationsrik bild av en utsträckt tid. Sångerna ger en stämning och en bild av Leenas upplevelse. För henne bildar sångerna ett sammanhängande minne. Fokus flyttas därmed från det yttre till det inre; Leenas medvetande är det centrala.

Alakoski refererar även till politiska skeenden för att antyda en tidsperiod. "Ibland tyckte jag att mamma såg lika ledsen ut som Biafrabarnen på teve." ${ }_{30}$ Kriget i Biafra pågick 1967-1970. Den fruktansvärda hungerkatastrofen utbröt 1968. Bilderna på svältande barn spreds över världen och gjorde outplånliga intryck. Att Leena tänker på barnen i Biafra när hon ser sin mammas uppgivna ansiktsuttryck är inte någon tillfällighet. Passagen återfinns i ett avsnitt om familjens fattigdom, och sammanställningen lyfter fram två upplevelser som satte sin prägel på Leenas barndom. Men tv-bilderna ger också en tidsstämning: flygplanskapningar, Idi Amin och Vietnamkriget.

På det här sättet skapar Susanna Alakoskis tidsreferenser en syntetisk tidsbild. Det kan ha en psykologisk-realistisk motivering. Det understryker hur minnet skapar sammanhängande gestalter, inte bara hos den unga flickan som tänkt berättare. Men det innebär också mindre risk för en fetischistisk fascination för tidsdetaljer. På några ställen anger Alakoski visserligen en detalj som direkt pekar ut ett år: "Alla i Fridhem verkade gladare sedan ABBA vunnit Eurovisionsschlagerfestivalen." ${ }_{11}$ Hon nämner dessutom enstaka årtal: "Sedan harklade hon sig och började prata om att 1975 var ett internationellt kvinnoår." ${ }_{32}$ Det sker dock på en av romanens sista sidor, som för att låta tiden sluta sig.

\section{Varumärken vs tidsmiljö och tidsdetaljer}

Finns det då några likheter mellan chick lit-genrens varumärkesfetischism och tidsmarkörerna i romaner om det nära förflutna? I chick lit-romanen pekar varumärken och designernamn ut ett tydligt tidssnitt, samtiden. De skapar en tidskänsla, men de definierar även en social miljö och bildar ett normsystem. Torbjörn Flygt och Susanna Alakoski

29 Susanna Alakoski, sid 94.

30 Susanna Alakoski, sid 70.

31 Susanna Alakoski, sid 195.

32 Susanna Alakoski, sid 253. 
antyder i stället en mer syntetisk tid, en period snarare än ett snitt. Det är allra tydligast hos Alakoski. Det kan bero på den sociala miljön. Både Svinalängorna och Underdog är moderna arbetarromaner, men Leenas familj befinner sig längre ner på samhällsstegen än Johans. Den definieras inte bara av klass, utan också av föräldrarnas alkoholism. Familjen får nöja sig med det som andra kasserat: möbler, skivor, kläder. Den har inte råd att leva i en hypostaserad tid på samma sätt som Flygts mer välanpassade arbetarfamilj, för att inte tala om Plum Sykes hjältinnor.

Men den syntetiska tiden ligger också mer i linje med Susanna Alakoskis estetik än med Torbjörn Flygts. Hon skapar en tänkt upplevelse hos en ung flicka, medan Flygt återskapar en tänkt uppväxt från den vuxne mannens perspektiv. Flickans spontana minne och den vuxnes medvetna minnesakt formar olika utryck. Därför blir också det normativa draget i Torbjörn Flygts tidsdetaljer tydligare. Hans musikaliska referenser är mer systematiska än Alakoskis och skapar snarare intrycket av en sorterad barndom än en upplevd sådan, som hos Alakoski. Det innebär också en ideologiserad barndom, mer i linje med Plum Sykes normativt konstruerade samtid.

Men alla romanerna vädjar till läsarens identifikationsvilja. Både Alakoski och Flygt skriver om 1970-talet på ett sätt som många läsare kan relatera till, inte bara de som växte upp då. Alakoski må vara mer sparsam än Flygt med tidsdetaljerna, men genom att skriva från barnets perspektiv om ett liv på trots mot omständigheterna låter hon texten växa till en bredare och mindre tidsbunden barndomskildring som läsaren kan relatera till, även den läsare som inte är stadigt förtöjd i det 1970-tal som Alakoski skriver om.

Denna bredare möjlighet finns kanske också i Flygts roman, i hans bild av den arbetande mamman. Men den är också så starkt inskriven i tiden att Flygts bild av tempoarbetet kanske inte vädjar till samma breda erfarenhet som till exempel pionjären Folke Fridells bild av fabriksmänniskan.

Även chick lit-romanen inbjuder till identifikation, men där Alakoskis och Flygts böcker om det nära förflutna ger läsaren möjlighet att identifiera sig med en erfarenhet vädjar chick lit snarare till drömmar. Samtidigt skapar de historiska romanerna en nostalgisk längtan efter något annat (1970-talet, barndomen). De tangerar därmed drömmen, alltså chick lit-genrens raison d'être. 